\title{
FLORA DE GRÃO-MOGOL, MINAS GERAIS
}

Com o presente fascículo do Boletim de Botânica da USP damos continuidade à publicação dos trabalhos sobre a flora da região de Grão-Mogol, área serrana situada no nordeste de Minas Gerais, Brasil. Os trabalhos são fruto de mais de duas décadas de pesquisa na região, e o principal objetivo dos mesmos foi efetuar um inventário da rica flora local, com muitos casos de espécies endêmicas. Desde 1998, uma vasta área daquela região foi decretada Parque Estadual, e os presentes trabalhos sobre a vegetação não só foram relevantes para a concretização dessa medida como serão, indubitavelmente, importantes para aprimorar o conhecimento e manejo das plantas dessa nova unidade de conservação.

O primeiro volume inteiramente dedicado à Flora de Grão-Mogol [vol. 21(2), outubro de 2003], trazia um artigo introdutório com dados gerais sobre a região, caracterização dos tipos vegetacionais e detalhamento do plano de trabalho executado, com síntese dos principais resultados florísticos obtidos, destacando-se que um total de 1073 espécies de plantas vasculares já foram coletadas na área de GrãoMogol. Em seguida, apareciam 36 dos artigos que compõem essa série, um deles sobre as pteridófitas, outro sobre a única família de gimnospermas ocorrente na área (Podocarpaceae), e 34 sobre famílias de angiospermas (de Acanthaceae a Droseraceae).

No segundo volume dedicado a essa série florística [22(2), dezembro de 2004], foram publicadas mais 39 famílias de angiospermas, de Ebenaceae até Oxalidaceae, e o terceiro volume [24(1), novembro de 2006] trouxe mais 26 famílias, de Palmae(Arecaceae) até Turneraceae.

O presente fascículo contém os tratamentos sobre 15 familias de angiospermas, incluindo Amaranthaceae, Convolvulaceae, Cyperaceae, Melastomataceae, Memecylaceae e as famílias de Ulmaceae até Xyridaceae, além de um adendo a Symplocaceae e um artigo sobre as briófitas (musgos e hepáticas, perfazendo 36 espécies na área). Cada trabalho foi executado por um ou mais pesquisadores colaboradores do projeto, e traz chaves de identificação de gêneros e espécies em cada família, descrições das espécies e, com poucas exceções, ilustrações de todas elas, além de dados sobre sua distribuição geográfica, habitats e fenologia. As famílias de maior diversidade neste volume são Melastomataceae com 43 espécies, Cyperaceae com 37 espécies, Malvaceae e Velloziaceae, cada uma com 18 espécies, e Convolvulaceae e Xyridaceae, cada uma com 17 espécies, sendo a maioria desses grupos relevantes por terem numerosos representantes típicos da vegetação de campo rupestre. Deve-se também destacar a descrição de uma espécie nova entre as Xyridaceae, que eleva o número de espécies endêmicas de Grão-Mogol para a cifra de 64. Para completar a Flora, falta apenas o tratamento de Eriocaulaceae, ainda em estudo.

Todos os artigos aqui apresentados foram avaliados, corrigidos e editorados pelo seguinte grupo editorial:

José Rubens Pirani (coordenação da edição) e Renato de Mello-Silva, do IB-USP;

Ana Maria Giulietti, Alessandro Rapini e Luciano Paganucci de Queiroz, da UEFS - Feira de Santana, Bahia;

Inês Cordeiro, do IBt - São Paulo;

Daniela C. Zappi, do RBG-Kew, Inglaterra. 